\title{
Perceived Religious Discrimination, Religiosity, and Life Satisfaction
}

\author{
Zoua M. Vang ${ }^{1} \cdot$ Feng $\mathrm{Hou}^{2} \cdot \mathrm{Katharine} \mathrm{Elder}^{1}$
}

Published online: 29 September 2018

(c) The Author(s) 2018

\begin{abstract}
Using a large national representative survey, this study examines the effect of perceived religious discrimination, religiosity, and their interaction on life satisfaction. The results show that the negative effect of religious discrimination on life satisfaction is large and equivalent to the effects of some major life events such as widowhood and unemployment. Higher religiosity is associated with higher levels of life satisfaction and tends to mitigate the negative effect of experiencing religious discrimination. Furthermore, although the prevalence of perceived religious discrimination varies across major religious faiths, its negative effect on life satisfaction is generally consistent. The implications of the findings for future research and theoretical development on religious discrimination and its associations with subjective well-being are discussed.
\end{abstract}

Keywords Life satisfaction $\cdot$ Canada $\cdot$ Religious discrimination $\cdot$ Religiosity · Multiculturalism $\cdot$ Social identity theory

\section{Introduction}

The growing number of immigrants from Asia, Africa and the Middle East to Canada, along with religious conversions, has contributed to a rise in minority religions, including Eastern Orthodox Christianity, Islam, Buddhism, Sikhism, Hinduism, and Judaism (Reitz et al. 2009). Over the 1981-2011 period, the share of the Canadian population self-identifying as Protestant or Catholic declined from over 90-69\%, while the share without a religious identification grew from 7 to $23 \%$. The population identifying with other religions increased from 2\% to $8 \%$ in 2011, and the largest increase is among Muslims which grew from less than half a percent to almost 3\% (Lee et al. 2017). Indeed, it is estimated that Canada's non-Christian religious population will grow to $14 \%$ by 2031, with Muslims, Hindus, Sikhs, and Buddhists spearheading this growth (Malenfant et al. 2010).

Zoua M. Vang

zoua.vang@mcgill.ca

1 Department of Sociology, McGill University, 717 Leacock Building, 855 Sherbrooke Street West, Montreal, QC H3A 2T7, Canada

2 Social Analysis Division, Statistics Canada, Ottawa, Canada 
The visible differentiation of these religious minorities along racial/ethnic lines may make them more prone to differential treatment, raising the question of how religious affiliation might affect experiences of discrimination and, related, subjective well-being (hereafter, well-being). This issue may have particular resonance for Muslim Canadians in the post-9/11 era of migration securitization. Studies have traced the rhetoric of "suspect minorities" to an undermined sense of citizenship (Nagra and Maurutto 2016), out-group distrust, and fear in Muslim communities (Jamil and Rousseau 2012). Religious-based hate crimes, such as the recent mass shooting of Muslims in a Quebec City mosque, are not a common phenomenon in Canada (Lum 2017). Even so, historical and contemporary claims for reasonable accommodation of religious difference (Conway 2012; Seijak 2008), ongoing debates about the secularization of public spaces (Elgazzar 2008), and increased securitization and concerns over religious radicalism (Bramadat and Dawson 2014) suggest that Canada's growing religious diversity is not without its challenges.

The growth of Canada's religious minorities, coupled with increased demands for secular public spaces, means that religious affiliation may be an important social marker that is susceptible to unequal treatment. Moreover, while members of all religious groups may be vulnerable to mistreatment in contexts of increased secularization, discrimination for members of non-Christian religions (e.g., Judaism, Islam, Buddhism, and Hinduism) may be especially acute given some of the overlap of religious minorities and visible minorities. ${ }^{1}$

Religious discrimination refers to the unequal treatment of individuals and/or groups based on religious beliefs (Equal Employment Opportunity Commission 2017). Religious discrimination differs from other forms of discrimination (e.g., gender or age discrimination) in that it can be perceived as a direct assault on an individual's belief system (Verkuyten and Yildiz 2007; Ysseldyk et al. 2010). Yet, there is surprisingly little scholarship on the association between religious discrimination and well-being. In this study, we address this lacuna by empirically examining the association between religious discrimination and life satisfaction for major Christian and non-Christian religious groups in Canada.

\subsection{Review of Religions and Religious Discrimination in Canada}

Like other settler societies, Christianity and colonialism go hand in hand when it came to Canada's nation-building project, resulting in the historical and contemporary dominance of Christianity in Canadian society (Bradford and Horton 2016; Christie and Gauvreau 2010; Delavignette 1964). However, as Beaman and Beyer (2008) note, there is a longstanding presence of religious minorities in Canada as well. For instance, Jewish communities were established in Canada as early as the 1700s and pockets of Muslims, Buddhists, Hindus, and Sikhs have been documented since the 1800s. Still, Catholics and Protestants dominated the religious landscape up until the 1970s when changes to the country's immigration policy opened the door for waves of non-European immigrants, many of whom were non-Christians (Knowles 2007).

Consistent with secular trends around the world, religious service attendance has declined overall in Canada today (Lee et al. 2017). Nonetheless, the proportion of the population identifying with a faith group remains relatively high. According to the 2011

\footnotetext{
1 Statistics Canada classifies visible minorities as "persons who are non-Caucasian in race or non-white in colour and who do not report being Aboriginal" (e.g. Chinese, South Asian, Black, Filipino, Latin American, Southeast Asian, Arab etc.) (Statistics Canada 2011).
} 
National Household Survey - the most recent, publicly available data on religious affiliation-just over 25 million people or $76 \%$ of the total population identified with a religious group (Statistics Canada 2016). Although Christians retain a stronghold (67\%), Buddhists, Hindus, Muslims, and Sikhs together constitute $7 \%$ of the population. Jews make up $1 \%$ and traditional Aboriginal spiritualists $0.19 \%$ of the population. These statistics lend credence to Canada's reputation as a multicultural society. Yet, as will be shown below, such religious diversity is not without tensions.

Canada has had its share of religious conflicts, with a long history of religious discrimination against religious minority groups (Beaman and Beyer 2008). One of the most well-documented case of religious (but also ethnic) discrimination is that of anti-semitism against Jewish Canadians (Brym et al. 1993; Prutschi 2004). There is some empirical evidence of religious discrimination against non-Judeo-Christian groups in Canada as well. According to the 2002 Ethnic Diversity Survey, religion was the fourth most cited reason behind visible minorities' self-reported discriminatory encounters (Reitz and Banerjee 2007). Race and ethnicity were the top two most cited reasons for discrimination. These findings suggest that religious discrimination may not be as prevalent as racial/ethnic discrimination in Canadian society. However, differential treatment based on religion may be less visible or perhaps masked relative to race/ethnicity because of the overlap of racial/ ethnic categories and minority religions.

There are a handful of studies that specifically examined religious discrimination in the Canadian labor and housing markets for visible minorities. For instance, Model and Lin (2002) found that foreign-born Muslims, Sikhs and to a lesser extent, Hindus, in Canada face a non-Christian penalty in the labor market (labor force participation, occupational status and unemployment) compared to native-born white Christians. Beyer (2005) also observed that Muslims face an earnings disadvantage despite being more educated than their Christian counterparts. Social distance among religious groups in Canada have also translated into spatial distance, with relatively higher levels of residential segregation for non-Christian groups compared to Christian denominations (Fong and Chan 2011). These studies indicate that religious discrimination is an important source of stratification in Canadian society.

The empirical evidence linking religious discrimination to well-being in Canada is sparse. In a recent study of Arab and Haitian immigrants in Montreal, Rousseau and colleagues (2011) found that Arab Muslims experienced an increase in discrimination-related psychological distress after 9/11. Although they did not exclusively measure religious discrimination per se, the positive association between discrimination and poor mental health for Arab Muslims, but not Arab non-Muslims, led the authors to conclude that religious discrimination, and Islamophobia more specifically, was responsible for the group's diminished psychological well-being. The study showed that Islamophobia is an important factor in reducing Muslim Canadians' mental health. Might religious discrimination more generally harm well-being for members of majority and minority religious faiths as well? The social psychological literature on social identity threat suggests that religious discrimination may indeed undermine well-being. We summarize this literature in the next section.

\subsection{Religious Discrimination, Social Identity Threat and Subjective Well-being}

We draw on social identity theory to situate the relationship between religious discrimination and well-being. According to this framework, social groups are an important source of individual and collective self-esteem for human beings (Tajfel and Turner 1979). Social 
groups provide its members with a sense of identity, belonging, and self-worth. Related, members' self-esteem is tied to the status of the social group. Enhanced group status will have positive effects on members' self-esteem. Conversely, when the social group's status is threatened or diminished, this can have dampening effects on members' self-esteem (Branscombe and Wann 1994; Cooper et al. 2017). Thus, members of disparaged social groups may experience a loss of well-being given the strong association between selfesteem and well-being (Pyszczynski et al. 2004).

The social psychological literature on social identity threat has amassed substantial and robust empirical evidence to support the theoretical assertion that attacks on social identity are harmful for well-being. For example, negative group stereotypes constitute a common form of social identity threat that has both behavioral and psychological consequences (Aronson et al. 2013; Spencer et al. 2016; Steele and Aronson 1995). Other forms of identity-based threats may include marginalized group status and the existence of prejudice and/or discrimination towards the social group by outsiders (Steele et al. 2002). Regardless of the form of social identity threat, a group's devaluation may trigger social psychological processes that directly and indirectly impact well-being (Greenfield and Marks 2007).

In the case of religious discrimination, being treated unfairly or differently by outsiders because of one's religion can signify to individuals that their group is less valued relative to others. It is this sense of perceived group devaluation that threatens social identity. Only a handful of empirical studies have tested this proposition. A study of Christians in the U.S. found that perceived religious discrimination was associated with stress among individuals who perceived themselves to be members of a sociocultural (but not numeric) minority group (Parent et al. 2018). Among religious minority groups, Jaspere et al. (2012) documented a significant positive association between religious discrimination and psychological distress (depression, anxiety, and psychosomatic symptoms) for Muslim women in New Zealand. This association was heightened in women who strongly identified as Muslim. Notably, even among atheists, individuals who perceived discrimination against their group had lower self-esteem and life satisfaction (Doane and Elliott 2015). Finally, a recent study of Christians, Protestants, Jews, and Muslims in the U.S. showed that perceived religious threat predicted lower sense of belonging for all four religious groups. However, this negative correlation was stronger for Jews and Muslims (Pasek and Cook 2017). Given the processes outlined by social identity theory and findings from these prior studies, we expect that religious discrimination will be negatively correlated with life satisfaction (H1). Moreover, this negative association will be present for members of both religious majority and minority groups $(\mathrm{H} 2)$.

\subsection{Religion, Religiosity and Subjective Well-Being}

While religious discrimination is expected to diminish well-being, religiosity may have the opposite effect. This supposition is based on the existing literature documenting the protective effects of religion and religiosity on well-being (George et al. 2002; Park 2007; Powell et al. 2003). Religiosity is a multidimensional concept that is related to but also distinct from religion. Whereas religion typically refers to a system of belief or worship, religiosity can encompass many components including the strength of an individual's religious beliefs or spirituality, religious social ties, salience of religious identity, and intensity or frequency of religious practices, among other things (Park 2007; Seeman et al. 2003; Stroope and Baker 2018). In this section, we summarize two theoretical frameworks that have been 
forwarded to explain the relationship between religion and well-being. These frameworks help delineate the processes underlying religiosity's salubrious effects.

According to the religious belonging thesis, organized religion allows for likeminded friendships and communities to form. Such religion-embedded networks may offer sources of material and emotional support as well as co-religious solidarity for members (Schieman et al. 2013; Lim and Putnam 2010). Unlike other secular forms of group membership (e.g., voluntary associations), however, there may be unique bonding resources available in religious communities, such as shared worldviews, a culture of mutual care and support, and closeness in status (Ellison et al. 1989; Ellison and George 1994; Kortt et al. 2015; Lim and Putnam 2010). Thus, the comfort and coping resources available in religion-based networks may differ from the resources available in other forms of group membership (Ysseldyk et al. 2014). Lim and Putnam (2010) accordingly argue that it is neither faith nor communities that matter for well-being but rather "communities of faith" (p. 927).

Proponents of the religious meaning thesis argue that belief in a "divine other" and perceived closeness to God may facilitate well-being by creating a sense of ontological security and personal import that enhances life satisfaction (Krause 2003; Pollner 1989). Pollner (1989) points to interactions with "symbolic others"- as opposed to real congregational interactions - as a potent force in structuring feelings of self-efficacy and empowerment. Without necessarily constituting an "objective" reality, Pollner argues, these "divine relations" can enhance one's sense of coherence and order, while mitigating stress and shame (Pollner 1989: 102). Moreover, dovetailing with the religious belonging thesis, a shared faith that is reinforced by co-religionists illustrates how "attendance and beliefs in the divine's causal relevance are linked to a sense that one matters to others" (Schieman et al. 2013: 459, emphasis added). In short, faith might allow religious group members to develop and maintain a sense of meaning in their lives and thus enhance well-being (Schieman et al. 2010).

With respect to religiosity, some scholars have argued that religious participation is a stronger, more consistent correlate of well-being than religious beliefs (Lim and Putnam 2010; Kortt et al. 2015). For instance, involvement in religious social activities have been found to positively enhance life satisfaction for older, widowed white females (Neill and Khan 1999). Likewise, the frequency of attending religious services has been shown to be another important aspect of religion that affects well-being (Ellison et al. 2001; Greenfield and Marks 2007). Religious attendance ensures regular interaction with other congregants, creating a sense of belonging reinforced by a "common set of beliefs, values, and interests" (Schieman et al. 2013: 459). Research from Australia (Kortt et al. 2015), Canada (Dilmaghani 2018; Gee and Veevers 1990), Europe (Greene and Yoon 2004), and the U.S. (Ellison et al. 2001; Green and Elliott 2010; Lim 2015) support the assertion that religious participation matters for well-being. In line with both the religious belonging and religious meaning theses, we hypothesize that there will be a positive correlation between religiosity and life satisfaction (H3).

Research also suggests that religiosity may moderate the negative association between religious discrimination and well-being. On the one hand, Jaspere et al. (2012) found that the inverse relationship between perceived religious discrimination and life satisfaction was attenuated for Muslim women who frequently engaged in religious practices (e.g., reading the Quaran, fasting during Ramadan, attending mosque, etc.). This means that religiosity can offset the harmful effects of religious discrimination. On the other hand, Ysseldyk and colleagues (2011) argued that spiritual components of religiosity may worsen well-being in the face of religious identity threat. This is because coping resources based on religious belief systems may be undermined in such situations. Their analysis of Muslim, Protestant, 
and Catholic university students showed that intrinsic aspects of religiosity increased sadness and anger after students were exposed to negative media portrayals of their faith (religious identity threat).

The rejection identification model (RIM), based on social identity theory, provides insights into why religiosity might mitigate the negative association between religious discrimination and well-being. According to the model, attributions of unfair treatment to prejudice or discrimination will negatively affect self-esteem and thereby lower wellbeing. This is because individuals who experience discrimination may internalize the negative treatment and/or feel a loss of control over their environment (Branscombe and Wann 1994; Branscombe et al. 1999). Yet, self-esteem may be protected even when faced with discrimination. This can occur when rejection by an outgroup leads to increased in-group identification (Branscombe et al. 1999). To the extent that religiosity reflects religious group identification, the RIM leads us to posit that high levels of religiosity would buffer individual well-being from the harmful effects of religious discrimination $(\mathrm{H} 4)$.

\section{Methodology}

\subsection{Data}

This study is based on Statistics Canada's (2013) General Social Survey (GSS). The GSS is an annual nationally representative household survey targeting the Canadian population aged 15 or older. Each GSS contains standard socio-demographic questions that are common across years, as well as a set of questions focusing on specific social or policy issues. The 2013 GSS focuses on social engagement and social networks. Interviews were conducted via either computer assisted telephone interviewing or electronic questionnaire. Respondents were interviewed in the official language (English or French) of their choice. The 2013 GSS oversampled immigrants to allow for refined analysis of the immigrant population. The overall response rate is $48.1 \%$. Survey weights were designed to adjust for non-responses and to account for possible over- and under-representation of geographic areas, age and sex groups. These weights are used in descriptive statistics and multivariate analysis. The total sample size is 27,695 . The analytical sample is based on 21,890 respondents who reported that they belong to a specific religious group.

\subsection{Measures}

\subsubsection{Life Satisfaction}

The outcome indicator in this study is self-reported life satisfaction. Life satisfaction can encompass one or more domains across work, home, and public life (Cummins 1996). Pavot and Diener (2008: 137) characterize life satisfaction as "a distinct construct representing a cognitive and global evaluation of the quality of one's life as a whole." Intimately linked to mental and physical health, lower levels of life satisfaction are significantly associated with obesity, heavy drinking, heart disease, depressive symptoms, and anxiety (Strine et al. 2008). Life satisfaction is also an important metric of integration and belonging for racial/ethnic minorities and religious groups, carrying real implications for individuals' engagement in and attachments to mainstream society (Verkuyten 2008). 
The 2013 GSS asked respondents: "Using a scale of 0-10 where 0 means "Very dissatisfied' and 10 means 'Very satisfied', how do you feel about your life as a whole right now?". This single item scale has been adopted extensively in national and international surveys and has been established as a reliable and valid indicator of individuals' well-being (Blanchflower 2009; Bonikowska et al. 2015; Diener et al. 2013). In the selected study sample, the mean score of life satisfaction is 7.97 , with a standard deviation of 1.75 .

\subsubsection{Religious Discrimination and Religiosity}

The key independent variable is the experience of religious discrimination. It is based on a single "yes" or "no" question: "In the past 5 years, have you experienced discrimination or been treated unfairly by others in Canada because of your religion?" In asking the question, the interviewer explained that "discrimination means treating people differently, negatively or adversely because of their race, age, religion, sex, etc." The similar screening question has been used in other surveys and studies (e.g. Mossakowski 2003; Noh et al. 1999). A limitation of a single yes or no question is that it does not capture the frequency or intensity of perceived religious discrimination.

Another focal independent variable is religiosity. It is a scale constructed from three survey questions. (A) "How important are your religious or spiritual beliefs to the way you live your life? Would you say they are 1-very important, 2-somewhat important, 3not very important, 4-not at all important. (B) "Not counting events such as weddings or funerals, during the past 12 months, how often did you participate in religious activities or attend religious services or meetings? 1-at least once a week, 2-at least once a month, 3-at least 3 times a year, 4-once or twice a year, 5-not at all." (C) "In the past 12 months, how often did you engage in religious or spiritual activities on your own, including prayer, meditation and other forms of worship taking place at home or in any other location? 1-at least once a day, 2-at least once a week, 3-at least once a month, 4 -at least 3 times a year, 5-once or twice a year, 6- not at all.” In constructing the scale, each item is reverse-coded and standardized with a mean of 0 and a standard deviation of 1 . The correlation among the three items ranges from 0.50 to 0.63 . The scale takes the mean of the three standardized items. The resultant scale has a mean of 0 and standard deviation of 0.84 , with a Cronbach alpha value of 0.79 . The same or similar composite index has been used in previous studies (e.g., Dilmaghani 2018), although some earlier studies use either these items separately or just one of the items (e.g. Leondari and Gialamas 2009; Lim and Putnam 2010). A composite index is preferable since these items capture different aspects (intrinsic and extrinsic) of religiosity and yet are highly correlated.

Since the experience of religious discrimination and the level of religiosity may vary across religions, we also control for major religious groups. They include Catholic, Protestant, Eastern Orthodox, Jewish, Muslim, Buddhist, Hindu, Sikh, and others. Roman Catholic, Protestant, and Eastern Orthodox are the three major divisions of Christianity. Judaism, Islam, Buddhism, Hinduism, and Sikhism are minority religions with sizable followers in Canada (Statistics Canada 2016). In regression models, they are coded as eight dummy variables, with the largest group_-Catholic_ as the reference category.

\subsubsection{Other Covariates}

Remaining covariates are chosen based on data availability and their relevance to life satisfaction as indicated in the literature (Blanchflower 2009; Diener et al. 1999; Easterlin 2003; 
Helliwell 2003; Hou 2014). These variables include age, gender, marital status, education, household income, employment status, immigrant status, social capital, and self-reported health. Age is coded as a single year; and the squared term of age is included to capture the U-shaped age profile of life satisfaction (Blanchflower and Oswald 2008; Frijters and Beatton 2012). Marital status is coded into five categories: married, common-law, widowed, separated or divorced, and single. Education is coded into five categories: university degree, some postsecondary education, high school graduation, less than high school graduation, and education not reported. Employment status is coded into three categories: employed, unemployed, and not in the labour force. Household income is coded as six categories: lowest (annual household income $<\$ 30,000)$, lower middle $(\$ 30,000-<\$ 60,000)$, middle $(\$ 60,000-<100,000)$, higher middle $(\$ 100,000-<\$ 150,000)$, highest $(\geq \$ 150,000)$, and income not reported. Social capital is measured by two indicators. One is the sense of belonging to local communities, coded as 1 -strong, 0 otherwise. The other is "knowing neighbours", coded as 1 -know many or most of the people in one's neighbourhood, 0 know a few or none. Self-assessed health status is a five-point ordinal scale coded as poor, fair, good, very good, and excellent.

\subsection{Analytical Strategy}

The analysis starts with descriptive statistics to show the prevalence of perceived religious discrimination and religiosity by religious group, as well as life satisfaction by perceived religious discrimination and religion. Furthermore, means and percentages of covariates are presented by the experience of discrimination.

In multivariate analysis, three OLS regression models are run sequentially by adding more explanatory variables in subsequent models. Model 1 includes religious discrimination, religiosity, and religious groups. This model shows whether the effects of religious discrimination and religiosity on life satisfaction are significant in the presence of each other and controlling for religious groups. Model 2 (the full model) adds the selected covariates, as specified in the previous section. The changes in the coefficients of religious discrimination and religiosity from Model 1 to Model 2 indicate the extent to which the effects of these two factors on life satisfaction are attributable to differences in the selected covariates among individuals who experienced or did not experience religious discrimination and with different levels of religiosity. Model 3 (the interaction model) adds the interaction between religious discrimination and religiosity. A significant positive interaction term would indicate that higher levels of religiosity tend to mitigate the negative effect of religious discrimination. In contrast, a significant negative interaction term suggests that higher levels of religiosity augment the negative effect of religious discrimination on life satisfaction. Alternatively, it can be interpreted that the effect of religiosity is conditioned on whether an individual experienced religious discrimination.

The full model and interaction model are also estimated for each of the eight identified religious groups separately. This stratified analysis shows whether the overall patterns observed in the full sample similarly apply to each religion.

In additional sensitivity analysis not shown here, alternative models were specified to treat life satisfaction as an ordinal measure using ordered probit models. Numerous studies have shown that treating life satisfaction as interval (with ordinary least-square regression models) or ordinal (with logistic or probit models) makes little difference in the sign and significance of its determinants (Ferrer-i-Carbonell and Frijters 2004; Frey and Stutzer 2000). This is also the case with the data of this study. Only linear model results are 
Table 1 Reported experience of discrimination and religiosity scores by religion group

\begin{tabular}{|c|c|c|c|c|c|c|c|}
\hline \multirow[b]{3}{*}{ Total } & \multirow{3}{*}{$\begin{array}{l}\text { Sample size } \\
21,890\end{array}$} & \multicolumn{3}{|c|}{$\%$ experienced discrimination } & \multicolumn{3}{|c|}{ Religiosity score } \\
\hline & & \multirow{2}{*}{$\begin{array}{c}\text { Percent } \\
5.8\end{array}$} & \multicolumn{2}{|c|}{$\begin{array}{l}\text { Lower and upper } \\
\text { confidence limit }\end{array}$} & \multirow{2}{*}{$\begin{array}{r}\text { Mean } \\
0.00\end{array}$} & \multicolumn{2}{|c|}{$\begin{array}{l}\text { Lower and upper } \\
\text { confidence limit }\end{array}$} \\
\hline & & & 5.5 & 6.1 & & -0.01 & 0.01 \\
\hline Catholic & 9890 & 2.6 & 2.3 & 2.9 & -0.13 & -0.14 & -0.11 \\
\hline Protestant & 8485 & 6.9 & 6.4 & 7.4 & 0.13 & 0.12 & 0.15 \\
\hline Eastern Orthodox & 501 & 6.0 & 3.9 & 8.1 & -0.04 & -0.11 & 0.02 \\
\hline Jewish & 251 & 22.1 & 16.9 & 27.2 & -0.19 & -0.29 & -0.10 \\
\hline Islam & 1074 & 21.4 & 19.0 & 23.9 & 0.35 & 0.30 & 0.39 \\
\hline Buddhist & 333 & 1.8 & 0.3 & 3.2 & -0.12 & -0.19 & -0.06 \\
\hline Hindu & 417 & 11.1 & 8.1 & 14.1 & 0.33 & 0.27 & 0.38 \\
\hline Sikh & 212 & 24.8 & 19.0 & 30.7 & 0.30 & 0.21 & 0.39 \\
\hline Others & 727 & 7.6 & 5.7 & 9.5 & -0.20 & -0.26 & -0.14 \\
\hline
\end{tabular}

Source: Statistics Canada (2013) General Social Survey on Social Identity

presented because it is straightforward to compare changes in the coefficients across linear models, but it is not so with logit or probit models (Mood 2010). ${ }^{2}$

\section{Results}

\subsection{Descriptive Statistics}

Table 1 shows the proportions of respondents who reported religious discrimination and religiosity scores by religious group. Among respondents who belonged to a religion, overall 5.8\% reported that they experienced religious discrimination in the past 5 years. This relatively low rate was partly related to the fact that about $48 \%$ of the religious population were Catholics and their rate of experiencing religious discrimination was low at $2.6 \%$. The rate was also low among Buddhists (1.8\%). In comparison, the rates were $24.8 \%$ among Sikhs, 22.1\% among Jews, and 21.4\% among Muslims. These results are consistent with those reported by Pasek and Cook (2017) in the U.S., where Jews and Muslims had higher perceptions of religious threat than Catholics and Protestants. There was also large group variation in religiosity. The average score was the highest among Muslims, followed by Hindus and Sikhs. The score was the lowest among Jews, followed by Catholics and Buddhists. Note that the religiosity scale was standardized with mean of 0 , so a negative value means that the level of religiosity for that particular group is lower than the sample average.

Table 2 shows life satisfaction by whether respondents experienced religious discrimination for each religious group. For the selected population as a whole, perceived religious discrimination is associated with a significantly lower level of life satisfaction. The difference in life satisfaction score between those who experienced religious discrimination

\footnotetext{
${ }^{2}$ Log odds ratios or odds ratios from logit or probit regression are affected by unobserved heterogeneity that may change values when an additional variable is added to the model even though the added variable is unrelated to the independent variables already in the model.
} 
Table 2 Life satisfaction by experience of discrimination and religious group

\begin{tabular}{|c|c|c|c|c|c|c|}
\hline \multirow[b]{3}{*}{ Total } & \multicolumn{3}{|c|}{$\begin{array}{l}\text { Not experienced dis- } \\
\text { crimination }\end{array}$} & \multicolumn{3}{|c|}{$\begin{array}{l}\text { Experienced discrimi } \\
\text { nation }\end{array}$} \\
\hline & \multirow{2}{*}{$\begin{array}{c}\text { Mean } \\
8.00\end{array}$} & \multicolumn{2}{|c|}{$\begin{array}{l}\text { Lower and } \\
\text { upper confi- } \\
\text { dence limit }\end{array}$} & \multirow{2}{*}{$\begin{array}{c}\text { Mean } \\
7.49\end{array}$} & \multicolumn{2}{|c|}{$\begin{array}{l}\text { Lower } \\
\text { and upper } \\
\text { confidence } \\
\text { limit }\end{array}$} \\
\hline & & 7.98 & 8.02 & & 7.39 & 7.60 \\
\hline Catholic & 8.00 & 7.96 & 8.05 & 7.08 & 6.82 & 7.33 \\
\hline Protestant & 8.05 & 8.01 & 8.09 & 7.75 & 7.60 & 7.89 \\
\hline Eastern Orthodox & 7.93 & 7.79 & 8.08 & 6.61 & 5.53 & 7.69 \\
\hline Jewish & 7.64 & 7.39 & 7.89 & 7.48 & 6.92 & 8.05 \\
\hline Islam & 8.07 & 7.96 & 8.19 & 7.33 & 7.07 & 7.59 \\
\hline Buddhist & 7.48 & 7.28 & 7.69 & 7.51 & 6.64 & 8.39 \\
\hline Hindu & 8.06 & 7.90 & 8.22 & 7.87 & 7.40 & 8.35 \\
\hline Sikh & 8.24 & 7.98 & 8.50 & 7.47 & 7.07 & 7.86 \\
\hline Others & 7.65 & 7.50 & 7.79 & 7.68 & 7.11 & 8.24 \\
\hline
\end{tabular}

Source: Statistics Canada (2013) General Social Survey on Social Identity

and those who did not experience was 0.51 in a 10 -point scale. This effect is similar to the difference in life satisfaction between the unemployed and the employed (0.39-0.56 depending on data and model specifications) or between widowed and currently married (0.35-0.54) individuals, as reported in recent previous studies using similar Canadian national survey data (Bonikowska et al. 2015; Hou 2014; Frank and Hou 2017). Again, there were large group variations in the effect of religious discrimination. The gap in life satisfaction associated with religious discrimination was large among Eastern Orthodox (1.32), Catholics (0.92), Sikhs (0.77), and Muslims (0.74), but was small and not significant among Jews, Buddhists, and Hindus.

As shown in Table 3, individuals who experienced religious discrimination were also different from those who did not in terms of the level of religiosity and various covariates. The experience of religious discrimination was associated with significantly higher levels of religiosity, younger age, being single, and having a university degree. Also, immigrants and the unemployed were more likely to report the experience of religious discrimination.

\subsection{Multivariate Regression Analyses}

Table 4 presents multivariate regression results. In Model 1, when religiosity and religious groups are controlled for, religious discrimination was associated with a gap of 0.63 in life satisfaction. Religiosity is positively and significantly associated with life satisfaction. Among the religious groups, Buddhists and Jews had lower life satisfaction than Catholics while the difference between Catholics and other religious groups was generally small and statistically insignificant. In Model 2, when all the selected covariates were controlled, the negative effect of religious discrimination was reduced to 0.39 , but remained statistically significant. The magnitude of the effect was similar to the difference in the same model between widowed and currently married individuals, or between unemployed and employed respondents, or between those with the lowest income and those with the highest 
Table 3 Means or percentages of covariates by experience of discrimination

\begin{tabular}{|c|c|c|c|c|c|c|}
\hline \multirow[b]{3}{*}{ Religiosity } & \multicolumn{3}{|c|}{ Not experienced discrimination } & \multicolumn{3}{|c|}{ Experienced discrimination } \\
\hline & \multirow{2}{*}{$\begin{array}{l}\text { Mean or percent } \\
-0.04\end{array}$} & \multicolumn{2}{|c|}{$\begin{array}{l}\text { Lower and upper } \\
\text { confidence limit }\end{array}$} & \multirow{2}{*}{$\begin{array}{l}\text { Mean or percent } \\
0.62\end{array}$} & \multicolumn{2}{|c|}{$\begin{array}{l}\text { Lower and } \\
\text { upper confi- } \\
\text { dence limit }\end{array}$} \\
\hline & & -0.05 & -0.03 & & 0.58 & 0.66 \\
\hline Age & 48.42 & 48.16 & 48.67 & 38.78 & 37.85 & 39.70 \\
\hline Woman (\%) & 53 & 53 & 54 & 53 & 50 & 55 \\
\hline \multicolumn{7}{|l|}{ Marital status } \\
\hline Married (\%) & 54 & 53 & 54 & 51 & 48 & 54 \\
\hline Common law (\%) & 11 & 10 & 11 & 4 & 3 & 5 \\
\hline Widowed (\%) & 6 & 6 & 6 & 2 & 1 & 3 \\
\hline Divorced or separated (\%) & 7 & 7 & 8 & 6 & 5 & 7 \\
\hline Single $(\%)$ & 23 & 22 & 23 & 37 & 34 & 39 \\
\hline \multicolumn{7}{|l|}{ Education } \\
\hline University degree $(\%)$ & 25 & 25 & 26 & 33 & 31 & 36 \\
\hline Some postsecondary (\%) & 33 & 32 & 33 & 28 & 26 & 31 \\
\hline High school graduation (\%) & 26 & 25 & 27 & 27 & 25 & 30 \\
\hline Less than high school (\%) & 16 & 15 & 16 & 11 & 9 & 13 \\
\hline Education not reported (\%) & 0 & 0 & 0 & 0 & 0 & 0 \\
\hline \multicolumn{7}{|l|}{ Household income } \\
\hline Lowest income (\%) & 11 & 11 & 12 & 13 & 11 & 15 \\
\hline Lower-middle income $(\%)$ & 20 & 20 & 21 & 22 & 20 & 24 \\
\hline Middle income $(\%)$ & 22 & 21 & 23 & 24 & 21 & 26 \\
\hline Higmidi $(\%)$ & 16 & 15 & 16 & 15 & 13 & 17 \\
\hline Highest income (\%) & 13 & 12 & 13 & 12 & 10 & 14 \\
\hline Income not reported (\%) & 18 & 18 & 19 & 14 & 12 & 16 \\
\hline Immigrants (\%) & 21 & 21 & 22 & 29 & 26 & 31 \\
\hline \multicolumn{7}{|l|}{ Employment status } \\
\hline Employed (\%) & 55 & 54 & 55 & 56 & 53 & 58 \\
\hline Unemployed (\%) & 2 & 2 & 2 & 4 & 3 & 5 \\
\hline Not in labour force $(\%)$ & 43 & 43 & 44 & 41 & 38 & 43 \\
\hline Community belonging (\%) & 82 & 81 & 82 & 78 & 76 & 81 \\
\hline Know neighbours (\%) & 45 & 44 & 45 & 36 & 33 & 39 \\
\hline \multicolumn{7}{|l|}{ General health } \\
\hline Excellent health (\%) & 23 & 23 & 24 & 21 & 19 & 23 \\
\hline Very good health $(\%)$ & 39 & 38 & 40 & 41 & 39 & 44 \\
\hline Good health (\%) & 27 & 26 & 27 & 25 & 23 & 27 \\
\hline Excellent health (\%) & 9 & 8 & 9 & 10 & 8 & 12 \\
\hline Very good health $(\%)$ & 3 & 2 & 3 & 3 & 2 & 4 \\
\hline
\end{tabular}

Source: Statistics Canada (2013) General Social Survey on Social Identity

income. The effect of religiosity was also reduced from Model 1 to Model 2. The effects of other covariates, particularly, age, marital status, employment status, income, social capital and general health, were generally consistent with the findings in the literature (e.g. Blanchflower 2009; Easterlin 2003; Helliwell 2003). 
Table 4 Regression models predicting life satisfaction

\begin{tabular}{|c|c|c|c|}
\hline & Model 1 & Model 2 & Model 3 \\
\hline Intercept & $8.01 * * *$ & $7.56 * * *$ & $7.56 * * *$ \\
\hline Experienced discrimination & $-0.63^{* * *}$ & $-0.39 * * *$ & $-0.61 * * *$ \\
\hline Religiosity & $0.20 * * *$ & $0.11 * * *$ & $0.09 * * *$ \\
\hline \multicolumn{4}{|l|}{ Religion (ref: Catholic) } \\
\hline Protestant & 0.03 & 0.00 & -0.01 \\
\hline Eastern Orthodox & -0.11 & -0.07 & -0.06 \\
\hline Jewish & $-0.23^{*}$ & $-0.30 * *$ & $-0.26 * *$ \\
\hline Islam & -0.03 & -0.04 & -0.02 \\
\hline Buddhist & $-0.49 * * *$ & $-0.20 \dagger$ & $-0.20 \dagger$ \\
\hline Hindu & 0.04 & 0.02 & 0.03 \\
\hline Sikh & 0.13 & 0.14 & 0.17 \\
\hline Others & $-0.28 * * *$ & $-0.14^{*}$ & $-0.15^{*}$ \\
\hline Age & & $-0.02 * * *$ & $-0.02 * * *$ \\
\hline Age squared & & $0.03 * * *$ & $0.03 * * *$ \\
\hline Woman & & 0.02 & 0.03 \\
\hline \multicolumn{4}{|l|}{ Marital status (ref: married) } \\
\hline Common law & & $-0.08^{*}$ & $-0.08^{*}$ \\
\hline Widowed & & $-0.39 * * *$ & $-0.39 * * *$ \\
\hline Divorced or separated & & $-0.58 * * *$ & $-0.58 * * *$ \\
\hline Single & & $-0.47 * * *$ & $-0.47 * * *$ \\
\hline \multicolumn{4}{|c|}{ Education (ref: university degree) } \\
\hline Some postsecondary & & 0.04 & 0.04 \\
\hline High school graduation & & $0.09 * *$ & $0.09 * *$ \\
\hline Less than high school & & $0.22 * * *$ & $0.22 * * *$ \\
\hline Education not reported & & $0.45^{*}$ & $0.45^{*}$ \\
\hline \multicolumn{4}{|l|}{ Income (ref: higher middle) } \\
\hline Lowest income & & $-0.26 * * *$ & $-0.26 * * *$ \\
\hline Lower-middle income & & $-0.09^{*}$ & $-0.09 *$ \\
\hline Middle income & & -0.03 & -0.03 \\
\hline Highest income & & $0.15 * * *$ & $0.15 * * *$ \\
\hline Income not reported & & $0.08^{*}$ & $0.08 *$ \\
\hline Immigrants & & $0.12 * * *$ & $0.13 * * *$ \\
\hline \multicolumn{4}{|l|}{ Employment (ref: employed) } \\
\hline Unemployed & & $-0.35 * * *$ & $-0.35 * * *$ \\
\hline Not in labour force & & 0.04 & 0.04 \\
\hline Community belonging & & $0.52 * * *$ & $0.52 * * *$ \\
\hline Know neighbours & & $0.21 * * *$ & $0.22 * * *$ \\
\hline \multicolumn{4}{|c|}{ General health(ref: good health) } \\
\hline Excellent & & $1.04 * * *$ & $1.04 * * *$ \\
\hline Very good & & $0.49 * * *$ & $0.49 * * *$ \\
\hline Fair & & $-0.70 * * *$ & $-0.70 * * *$ \\
\hline Poor & & $-1.51 * * *$ & $-1.51 * * *$ \\
\hline Discrimination $*$ religiosity & & & $0.37 * * *$ \\
\hline R squared & 0.016 & 0.186 & 0.187 \\
\hline
\end{tabular}

Source: Statistics Canada (2013) General Social Survey on Social Identity 
Table 4 (continued)

The difference is significant at ${ }^{\dagger} p<0.10$; $* p<0.05 ; * * p<0.01$; $* * * p<0.001$

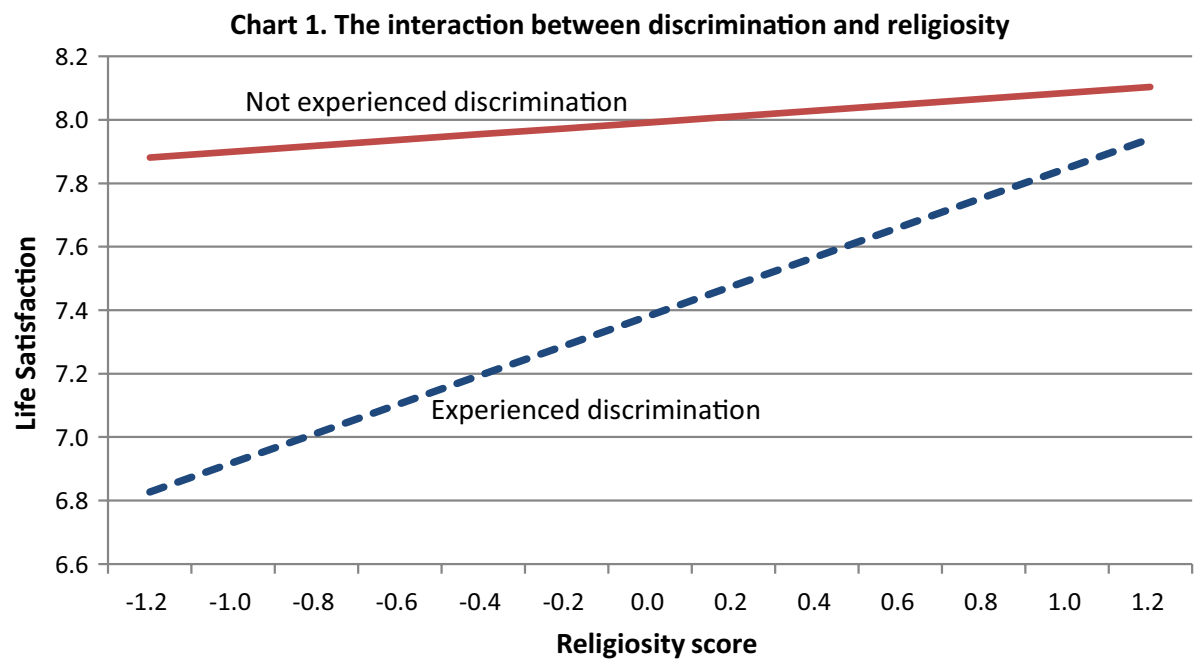

Fig. 1 The interaction between discrimination and religiosity

Model 3 in Table 4 adds the interaction between religious discrimination and religiosity. The interaction term was statistically significant and positive, implying that higher religiosity helped to mitigate the negative effect of religious discrimination on life satisfaction. Figure 1 plots the interaction effect using the model estimates. It shows that when religiosity was one standard deviation (score -0.84 ) below the mean, the gap in life satisfaction associated with religious discrimination was about 0.92 in a scale from 0 to 10 . The gap narrowed to 0.30 where religious score was one standard deviation (0.84) above the mean. The figure also shows that the positive effect of religiosity was much stronger among those who reported religious discrimination than among those who did not.

Table 5 presents the estimates of Model 2 (the full model) and Model 3 (the interaction model) for each identified religious group. We present only the coefficients of religious discrimination and religiosity (the full model) as well as their interaction effect (the interaction model) for parsimony. For all religious groups, except Buddhists, religious discrimination was associated with lower levels of life satisfaction. The coefficient of religious discrimination for Sikhs was also negative but significant only at a threshold less demanding than the conventional $p<0.05$ level (i.e., marginally significant). Higher religiosity was associated with greater life satisfaction in the full model for all groups except for Buddhists. Religiosity was positively correlated with life satisfaction for Jews as well but this association was again marginally significant. In the interaction model, the interaction between religious discrimination and religiosity was positive and highly significant only for Protestants and Eastern Orthodox Christians, and marginally significant for Jews. The interaction was positive but not statistically significant for Catholics and Sikhs; and it was negative but not significant for Buddhists and Hindus. 
Table 5 The effect of discrimination and religiosity on life satisfaction by religious group

\begin{tabular}{|c|c|c|}
\hline & Full model & Interaction model \\
\hline \multicolumn{3}{|l|}{ Catholic } \\
\hline Experienced discrimination & $-0.75^{* * *}$ & $-0.81 * * *$ \\
\hline Religiosity & $0.10 * * *$ & $0.10 * * *$ \\
\hline Discrimination * Religiosity & & 0.14 \\
\hline \multicolumn{3}{|l|}{ Protestant } \\
\hline Experienced discrimination & $-0.14 *$ & $-0.46^{* * *}$ \\
\hline Religiosity & $0.11 * * *$ & $0.10 * * *$ \\
\hline Discrimination * Religiosity & & $0.37 * *$ \\
\hline \multicolumn{3}{|l|}{ Eastern Orthodox } \\
\hline Experienced discrimination & $-1.23 * * *$ & $-1.56^{* * *}$ \\
\hline Religiosity & $0.31 * *$ & 0.15 \\
\hline Discrimination * Religiosity & & $1.63 * * *$ \\
\hline \multicolumn{3}{|l|}{ Jewish } \\
\hline Experienced discrimination & $-0.61 *$ & $-0.62 *$ \\
\hline Religiosity & $0.27 \dagger$ & 0.11 \\
\hline Discrimination * Religiosity & & $0.63 \dagger$ \\
\hline \multicolumn{3}{|l|}{ Islam } \\
\hline Experienced discrimination & $-0.65 * * *$ & $-0.68 * * *$ \\
\hline Religiosity & $0.25^{* * * *}$ & $0.25^{* *}$ \\
\hline Discrimination $*$ Religiosity & & 0.06 \\
\hline \multicolumn{3}{|l|}{ Buddhist } \\
\hline Experienced discrimination & 0.97 & 0.97 \\
\hline Religiosity & 0.02 & 0.02 \\
\hline Discrimination * Religiosity & & -0.23 \\
\hline \multicolumn{3}{|l|}{ Hindu } \\
\hline Experienced discrimination & $-0.37 \dagger$ & -0.17 \\
\hline Religiosity & $0.38 * *$ & $0.43 * * *$ \\
\hline Discrimination * Religiosity & & -0.50 \\
\hline \multicolumn{3}{|l|}{ Sikh } \\
\hline Experienced discrimination & $-0.80 * *$ & $-1.00 * *$ \\
\hline Religiosity & $0.39 *$ & 0.30 \\
\hline Discrimination * Religiosity & & 0.68 \\
\hline
\end{tabular}

Source: Statistics Canada (2013) General Social Survey on Social Identity

Significant at ${ }^{\dagger} p<0.10, * p<0.05, * * p<0.01$, *** $p<0.001$. Both models also include the covariates included in Model 2 of Table 4

\section{Discussion}

\subsection{Main Findings}

There has been a resurgence of research on religious discrimination in North America and Europe following 9/11 (Fox 2007). Yet there is a paucity of research on the consequences of religious discrimination for well-being. The present study strives to fill this empirical gap by using nationally representative data from Canada. Consistent with social identity theory 
(Tajfel and Turner 1979), we found that religious discrimination was negatively associated with life satisfaction (H1). Although the prevalence of religious discrimination varied across religions - with Jews, Muslims and Sikhs standing out as the groups with the most perceived unequal treatment - religious discrimination diminished the well-being of both majority and minority religious group members alike. Notably, the negative effect of religious discrimination on life satisfaction was large and equivalent to the effects of some major life events such as widowhood and unemployment.

Contrary to our expectations of uniform effects of religious discrimination on life satisfaction across all religious traditions, we found that the association was not statistically significant for Buddhists and marginally significant for Sikhs (H2). Buddhism's emphasis on nonattachment might explain why very few Buddhists perceived religious discrimination and the well-being of members who encountered religious discrimination was not diminished (Lim 2015). In other words, the notion that one should not be consumed by (and dwell on) thingse.g., material belongings, social relations, and experiences - could provide a powerful psychological buffer against assaults to religious identity, and in turn, life satisfaction. However, caution should be exercised in interpreting the results for Buddhists in this study since their sample size is small. More research is needed to determine if Buddhism truly offers members an immunity against religious discrimination's deleterious effects.

As expected, and consistent with the religious belonging and religious meaning theses (Krause 2003; Lim and Putnam 2010; Pollner 1989; Schieman et al. 2013), religiosity was positively associated with life satisfaction $(\mathrm{H} 3)$. Our measure of religiosity included dimensions of religious participation and engagement. Individuals who regularly participate in religious or spiritual activities - whether in formal group settings or informally on their ownmight derive objective support from other congregants. Religiosity may be tapping into the strength of the divine relationship as well. Individuals who are more religious may have a stronger symbolic relationship with their deity, and in turn, derive emotional and psychological support from a divine other (Pollner 1989). The positive association between religiosity and life satisfaction suggests that group identification may act as a key buffer against perceived discrimination. Moreover, the support derived from both social and divine relations may be especially conducive to this protective function.

Consistent with the RIM (Branscombe and Wann 1994; Branscombe et al. 1999), religiosity also lessened the negative association between religious discrimination and life satisfaction (H4). This buffering effect is similar to Jaspere and colleagues' (2012) findings for Muslims in New Zealand. Notably, in our study this was not the case for Muslims. Religiosity mitigated discrimination's dampening effect on life satisfaction for Protestants, Eastern Orthodox Christians, and Jews (marginally). However, the interaction term was not statistically significant for other religious groups. It is possible that for members of other religious groups, especially minority religions where there may be overlap with racial/ethnic minority status, religiosity is insufficient to protect self-esteem from discrimination. Members of minority religions, such as Muslims and Sikhs, who experience religious discrimination may also encounter racial/ethnic discrimination simultaneously. As such, life satisfaction may be under attack from multiple sources of discrimination and religiosity may not be enough to allow individuals to cope with non-religious forms of discrimination.

\subsection{Contributions and Limitations}

The study has some limitations. First, the relationship between religiosity and life satisfaction may be spurious because people with a more positive outlook and temperament may 
self-select into religious communities (Verkuyten 2008). Second, life satisfaction measures only the cognitive dimension of well-being (Kortt et al. 2015). Future studies should also investigate the association between religious discrimination and affective dimensions of well-being (e.g., emotions and moods) to produce more thorough knowledge about the psychological consequences of religious discrimination for individuals.

A third limitation is that the mechanisms underlying the relationship between religious discrimination and life satisfaction remain untested in the current study. Social identity theory posits that self-esteem is a key mechanism linking social identity threat to poor wellbeing. Previous studies have examined self-esteem in relation to social identity and wellbeing (Branscombe and Wann 1994; Branscombe et al. 1999; Cooper et al. 2017; Doane and Elliott 2015), but none assessed religious identity threat and its associations with self-esteem. We, too, were unable to examine this relationship due the lack of self-esteem measures in the GSS. Yet, the centrality of self-esteem in social identity theory points to the need for empirical validation, especially with regards to possible differential effects for religious majority and minority group members. In other words, whether personal and collective self-esteem is negatively impacted by discrimination may be contingent on the relative status of the disparaged religious group. A religious group that has a dominant status in society, and is therefore more powerful, may have more available resources to either alleviate or remove the source of the social identity threat; thereby, immunizing its members' self-esteem from further attacks. In contrast, a low status religious group may lack sufficient power and influence to protect its members from outside assaults. As such, members' self-esteem and well-being may be more vulnerable.

Finally, the cross-sectional nature of our data should also be taken into consideration. First, causal inferences about the effects of religious discrimination or religiosity on life satisfaction may be limited. This is because with observational data, biased estimates may arise from measurement error in predictor variables, reverse causality, omitted variable bias, or selection bias (Nichols 2007). In our study, threats to causal interpretation might plausibly arise from measurement error in religious discrimination. Self-reported discrimination measures are subject to perceptual biases (Kaiser and Major 2006). Vigilance bias-reporting discrimination when there is none-would result in an overestimation of the negative coefficient on religious discrimination in models predicting life satisfaction. In contrast, minimization bias-denying or failing to notice discrimination altogether-would result in an underestimation of discrimination's harmful effects on well-being. Second, observational data does not allow us to examine how religious discrimination, religiosity, and life satisfaction - and the relationships among them-may change over time. Earlier, we alluded to the fact that religious hate crimes are a rare phenomenon in Canada. Yet, as with other Western societies, Islamophobia is on the rise in Canada, as evidenced by attitudinal surveys and legislation targeted at Muslims such as Quebec's Bill 62 ban on face coverings (Bilodeau et al. 2018; Steuter-Martin 2017). How such changing sociopolitical climates affect perceptions of religious discrimination, religiosity, and life satisfaction is unknown.

Despite the limitations, this study contributes to the literature on discrimination and well-being by providing a reliable analysis of the association between religious discrimination and religiosity on life satisfaction based on a large nationally representative sample. We also demonstrate the effect of religiosity on well-being and its significant role in moderating the association between religious discrimination and subjective well-being. The large national survey also allowed us to examine multiple religious faiths in Canada. The study provides an important springboard for future theoretical development on religious discrimination and the pathways through which it affects well-being. 


\section{Conclusion}

Scholars have amassed substantial empirical evidence and developed sophisticated theoretical frameworks for the harmful effects of racial/ethnic discrimination on health. In comparison, less attention has been given to the consequences of religious discrimination. Against the rise of Islamophobia in Western countries, coupled with the tide of secularism that is increasingly edging religion out of public life, members of faith communities may be susceptible to assaults on their religious identity and beliefs. How and why such assaults impact individual well-being is an area of research that requires greater attention. A better understanding of the prevalence and consequences of religious discrimination in Canada might also provide pertinent information for policymakers to facilitate more harmonious intergroup relations and minimize the negative sociopsychological effects of discrimination for individuals and groups.

Open Access This article is distributed under the terms of the Creative Commons Attribution 4.0 International License (http://creativecommons.org/licenses/by/4.0/), which permits unrestricted use, distribution, and reproduction in any medium, provided you give appropriate credit to the original author(s) and the source, provide a link to the Creative Commons license, and indicate if changes were made.

\section{References}

Aronson, J., Burgess, D. J., Phelan, S. M., \& Juarez, L. (2013). Unhealthy interactions: The role of stereotype threat in health disparities. American Journal of Public Health, 103(1), 50-56.

Beaman, L. G., \& Beyer, P. (Eds.). (2008). Religion and diversity in Canada. Leiden: Brill.

Beyer, P. (2005). Religious identity and educational attainment among recent immigrants to Canada: Gender, age, and 2nd generation. Journal of International Migration and Integration, 6, 177-199.

Bilodeau, A., Turgeon, L., White, S., \& Henderson, A. (2018). Strange bedfellows? Attitudes toward minority and majority religious symbols in the public sphere. Politics and Religion, 11, 309-333.

Blanchflower, D. G. (2009). International evidence on well-being. In A. B. Krueger (Ed.), National time accounting and subjective well-being (pp. 155-226). Chicago: University of Chicago Press.

Blanchflower, D. G., \& Oswald, A. J. (2008). Is well-being u-shaped over the life cycle? Social Science and Medicine, 66, 1733-1749.

Bonikowska, A., Helliwell, J. F., Hou, F., \& Schellenberg, G. (2015). An assessment of life satisfaction responses on recent Statistics Canada surveys. Social Indicators Research, 118, 617-643.

Bradford, J. T., \& Horton, C. (2016). Mixed blessings: Indigenous encounters with Christianity in Canada. Vancouver: University of British Columbia Press.

Bramadat, P., \& Dawson, L. L. (2014). Religious radicalization and securitization in Canada and beyond. Toronto: University of Toronto Press.

Branscombe, N. R., Schmitt, M. T., \& Harvey, R. D. (1999). Perceiving pervasive discrimination among African Americans: Implications for group identification and well-being. Journal of Personality and Social Psychology, 77(1), 135-149.

Branscombe, N. R., \& Wann, D. L. (1994). Collective self-esteem consequences of outgroup derogation when a valued social identity is on trial. European Journal of Social Psychology, 24, 641-657.

Brym, R. J., Shaffir, W., \& Weinfeld, M. (1993). The Jews in Canada. Toronto: Oxford University Press.

Christie, N., \& Gauvreau, M. (2010). Christian Churches and their peoples, 1840-1965: A social history of religion in Canada. Toronto: University of Toronto Press.

Conway, K. (2012). Quebec's Bill 94: What's 'reasonable'? what's 'accommodation'? and what's the meaning of the Muslim veil? American Review of Canadian Studies, 42, 195-209.

Cooper, K., Smith, L. G. E., \& Russell, A. (2017). Social identity, self-esteem, and mental health in autism. European Journal of Social Psychology, 47(7), 844-854.

Cummins, R. A. (1996). The domains of life satisfaction: An attempt to order chaos. Social Indicators Research, 38(3), 303-328.

Delavignette, R. (1964). Christianity and colonialism. New York: Hawthorne Books. 
Diener, E., Inglehart, R., \& Tay, L. (2013). Theory and validity of life satisfaction scales. Social Indicators Research, 112, 497-527.

Diener, E., Suh, E. M., Lucas, R. E., \& Smith, H. L. (1999). Subjective well-being: Three decades of progress. Psychology Bulletin, 125, 276-302.

Dilmaghani, M. (2018). Religiosity and subjective wellbeing in Canada. Journal of Happiness Studies, 19, 629-647.

Doane, M. J., \& Elliott, M. (2015). Perceptions of discrimination among atheists: Consequences for aitheist identification, psychological and physical well-being. Psychology of Religion and Spirituality, 7(2), $130-141$.

Easterlin, R. A. (2003). Explaining happiness. Proceedings of the National Academy of Sciences, 100, $11176-11183$.

Elgazzar, S. (2008). The sacred public sphere: Praying for secularism. Canadian Diversity, 6, 116-118.

Ellison, C. G., Boardman, J. D., Williams, D. R., \& Jackson, J. S. (2001). Religious involvement, stress, and mental health: Findings from the 1995 Detroit Area Study. Social Forces, 80, 215-249.

Ellison, C. G., Gay, D. A., \& Glass, T. A. (1989). Does religious commitment contribute to individual life satisfaction? Social Forces, 68, 100-123.

Ellison, C. G., \& George, L. K. (1994). Religious involvement, social ties, and social support in a Southeastern community. Journal for the Scientific Study of Religion, 33, 46-61.

Equal Employment Opportunity Commission. (2017). Religious discrimination. https://www1.eeoc.gov// laws/types/religion.cfm?renderforprint=1. Accessed 15 April 2017.

Ferrer-i-Carbonell, A., \& Frijters, P. (2004). How important is methodology for the estimates of the determinants of happiness? The Economic Journal, 114, 641-659.

Fong, E., \& Chan, E. (2011). Residential patterns among religious groups in Canadian cities. City \& Community, 10, 393-413.

Fox, J. (2007). Religious discrimination: A world survey. Journal of International Affairs, 61, 47-67.

Frank, K., \& Hou, F. (2017). Over-education and well-being: How does education-occupation mismatch affect the life satisfaction of university-educated immigrants and non-immigrant workers. Ethnicity and Health. https://doi.org/10.1080/13557858.2017.1316832.

Frey, B. F., \& Stutzer, A. (2000). Happiness, economy and institutions. Economic Journal, 110, 918-938.

Frijters, P., \& Beatton, T. (2012). The mystery of the u-shaped relationship between happiness and age. Journal of Economic Behavior \& Organization, 82, 525-542.

Gee, E. M., \& Veevers, J. E. (1990). Religious involvement and life satisfaction in Canada. Sociology of Religion, 51(4), 387-394.

George, L. K., Ellison, C. G., \& Larson, D. B. (2002). Explaining the relationships between religious involvement and health. Psychological Inquiry, 13, 190-200.

Green, M., \& Elliott, M. (2010). Religion, health, and psychological well-being. Journal of Religion and Health, 49(2), 149-163.

Greene, K. V., \& Yoon, B. J. (2004). Religiosity, economics and life satisfaction. Review of Social Economy, 62(2), 245-261.

Greenfield, E. A., \& Marks, N. F. (2007). Religious social identity as an explanatory factor for associations between more frequent formal religious participation and psychological well-being. The International Journal for the Psychology of Religion, 17(3), 245-259.

Helliwell, J. F. (2003). How's life? Combining individual and national variables to explain subjective wellbeing. Economic Modelling, 20, 331-360.

Hou, F. (2014). Keep up with the Joneses or keep on as their neighbours: Life satisfaction and income in Canadian urban neighbourhoods. Journal of Happiness Studies, 15, 1085-1107.

Jamil, U., \& Rousseau, C. (2012). Subject positioning, fear, and insecurity in South Asian Muslim communities in the War on Terror context. Canadian Review of Sociology, 49, 370-388.

Jaspere, M., Ward, C., \& Jose, P. E. (2012). Identity, perceived religious discrimination, and psychological well-being in Muslim immigrant women. Applied Psychology, 61(2), 250-271.

Kaiser, C. R., \& Major, B. (2006). A social psychological perspective on perceiving and reporting discrimination. Law \& Social Inquiry, 31(4), 801-830.

Knowles, V. (2007). Strangers at our gates: Canadian immigration and immigration policy, 1540-2006. Toronto: Dundrum. (revised ed.).

Kortt, M. A., Dollery, B., \& Grant, B. (2015). Religion and life satisfaction down under. Journal of Happiness Studies, 16, 277-293.

Krause, N. (2003). Religious meaning and subjective well-being in late life. The Journals of Gerontology Series B: Psychological Sciences and Social Sciences, 58, S160-S170.

Lee, S., Hou, F., Edmonston, B., \& Wu, Z. (2017). Religious intermarriage in Canada, 1981 to 2011. Journal for the Scientific Study of Religion, 56(3), 667-677. 
Leondari, A., \& Gialamas, V. (2009). Religiosity and psychological well-being. International Journal of Psychology, 44, 241-248.

Lim, C. (2015). Religion and subjective well-being across religious traditions: Evidence from 1.3 million Americans. Journal for the Scientific Study of Religion, 54, 684-701.

Lim, C., \& Putnam, R. D. (2010). Religion, social networks, and life satisfaction. American Sociological Review, 75, 914-933.

Lum, F. (2017). The Quebec City mosque attack: What we know so far. The globe and mail, 30 January 2017. https://beta.theglobeandmail.com/news/national/quebec-city-mosque-shooting-what-weknow-so-far/article33826078/?ref=http://www.theglobeandmail.com. Accessed 10 Mar 2017.

Malenfant, E. C., Lebel, A., \& Martel, L. (2010). Projections of the diversity of the Canadian population: 2006 to 2031. Ottawa: Statistics Canada, Catalogue No. 91-551-X.

Model, S., \& Lin, L. (2002). The cost of not being Christian: Hindus, Sikhs and Muslims in Britain and Canada. International Migration Review, 36, 1061-1092.

Mood, C. (2010). Logistic regression: Why we cannot do what we think we can do, and what we can do about it. European Sociological Review, 26, 67-82.

Mossakowski, K. N. (2003). Coping with perceived discrimination: Does ethnic identity protect mental health? Journal of Health and Social Behavior, 44, 318-331.

Nagra, B., \& Maurutto, P. (2016). Crossing borders and managing racialized identities: Experiences of security and surveillance among young Canadian Muslims. Canadian Journal of Sociology, 41, $165-194$.

Neill, C. M., \& Kahn, A. S. (1999). The role of personal spirituality and religious social activity on the life satisfaction of older widowed women. Sex Roles, 40, 319-329.

Nichols, A. (2007). Causal inference with observational data. The Stata Journal, 7(4), 507-541.

Noh, S., Beiser, M., Kaspar, V., Hou, F., \& Rummens, J. (1999). Perceived racial discrimination, depression, and coping: A study of Southeast Asian refugees in Canada. Journal of Health and Social Behavior, 40, 193-207.

Parent, M. C., Brewster, M. E., Cook, S. W., \& Harmon, K. A. (2018). Is minority stress in the eye of the beholder? A test of minority stress theory with Christians. Journal of Religion and Health. https:// doi.org/10.1007/s10943-017-0550-6.

Park, C. L. (2007). Religiousness/spirituality and health: A meaning systems perspective. Journal of Behavioral Medicine, 30, 319-328.

Pasek, M. H., \& Cook, J. E. (2017). Religion from the target's perspective: A portrait of religious threat and its consequences in the United States. Social Psychological and Personality Science. https:// doi.org/10.1177/1948550617739089.

Pavot, W., \& Diener, E. (2008). The satisfaction with life scale and the emerging construct of life satisfaction. The Journal of Positive Psychology, 3, 137-152.

Pollner, M. (1989). Divine relations, social relations, and well-being. Journal of Health and Social Behavior, 30, 92-104.

Powell, L. H., Shahabi, L., \& Thoresen, C. E. (2003). Religion and spirituality: Linkages to physical health. American Psychologist, 58, 36-52.

Prutschi, M. (2004). Anti-semitism in Canada. Jewish Political Studies Review, 16, 105-117.

Pyszczynski, T., Greenberg, J., Solomon, S., Arndt, J., \& Schimel, J. (2004). Why do people need selfesteem: A theoretical and empirical review. Psychological Bulletin, 130, 435-468.

Reitz, J. G., \& Banerjee, R. (2007). Racial inequality, social cohesion and policy issues in Canada. In K. Banting, T. J. Courchene, \& F. L. Seidle (Eds.), Belonging? Diversity, recognition and shared citizenship in Canada (pp. 1-57). Montreal: Institute for Research on Public Policy.

Reitz, J. G., Banerjee, R., Phan, M., \& Thompson, J. (2009). Race, Religion, and the social integration of new immigrant minorities in Canada. International Migration Review, 43, 695-726.

Rousseau, C., Hassan, G., Moreau, N., \& Thombs, B. D. (2011). Perceived discrimination and its associations with psychological distress among newly arrived immigrants before and after September 11, 2001. American Journal of Public Health, 101(5), 909-915.

Schieman, S., Bierman, A., \& Ellison, C. G. (2010). Religious involvement, beliefs about God, and the sense of mattering among older adults. Journal for the Scientific Study of Religion, 49, 517-535.

Schieman, S., Bierman, A., \& Ellison, C. G. (2013). Religion and mental health. In C. S. Aneshensel, J. C. Phelan, \& A. Bierman (Eds.), Handbook of the sociology of mental health (pp. 457-478). New York: Springer.

Seeman, T. E., Dubin, L. F., \& Seeman, M. (2003). Religiosity/spirituality and health: A critical review of the evidence for biological pathways. American Psychologist, 58(1), 53-63.

Seijak, D. (2008). Secularization and the separation of church and state in Canada. Canadian Diversity, 6, 6-24. 
Spencer, S. J., Logel, C., \& Davies, P. G. (2016). Stereotype threat. Annual Review of Psychology, 67, 415-437.

Statistics Canada. (2011). Immigration and ethnocultural diversity in Canada. Ottawa: Statistics Canada, Catalogue No. 99-010-X2011001.

Statistics Canada. (2013). General social survey: An overview, 2013. Ottawa: Statistics Canada, Catalogue No. $89 \mathrm{~F} 0115 \mathrm{X}$.

Statistics Canada. (2016). Canadian demographics at a glance (2nd ed.). Ottawa: Statistics Canada, Catalogue No. 91-003-X.

Steele, C. M., \& Aronson, J. (1995). Stereotype threat and the intellectual test performance of African Americans. Journal of Personality and Social Psychology, 69, 797-811.

Steele, C. M., Spencer, S. J., \& Aronson, J. (2002). Contending with group image: The psychology of stereotype and social identity threat. Advances in Experimental Social Psychology, 34, 379-440.

Steuter-Martin. (2017). Breaking down Bill 62: What you can and can't do while wearing a niqab in Quebec. $\quad C B C$. https://www.cbc.ca/news/canada/montreal/bill-62-examples-ministry-release-1.4369347. Accessed 2 May 2018.

Strine, T. W., Chapman, D. P., Balluz, L. S., Moriarty, D. G., \& Mokdad, A. H. (2008). The associations between life satisfaction and health-related quality of life, chronic illness, and health behaviors among U.S. community-dwelling adults. Journal of Community Health, 33, 40-50.

Stroope, S., \& Baker, J. O. (2018). Whose moral community? Religiosity, secularity, and self-rated health across communal religious contexts. Journal of Health and Social Behavior, 59(2), 185-199.

Tajfel, H., \& Turner, J. (1979). An integrative theory of intergroup conflict. In W. Austin \& S. Worchel (Eds.), The social psychology of intergroup relations (pp. 33-47). Monterey, CA: Brooks/Cole.

Verkuyten, M. (2008). Life satisfaction among ethnic minorities: The role of discrimination and group identification. Social Indicators Research, 89, 391-404.

Verkuyten, M., \& Yildiz, A. A. (2007). National (dis)identification and ethnic and religious identity: A study among Turkish-Dutch Muslims. Personality and Social Psychology Bulletin, 33, 1448-1462.

Ysseldyk, R., Matheson, K., \& Anisman, H. (2010). Religiosity as identity: Toward an understanding of religion from a social identity perspective. Personality and Social Psychology Review, 14, 60-71.

Ysseldyk, R., Matheson, K., \& Anisman, H. (2011). Coping with identity threat: The role of religious orientation and implications for emotions and action intentions. Psychology of Religion and Spirituality, $3(2), 132-148$.

Ysseldyk, R., Talebi, M., Matheson, K., Bloemraad, I., \& Anisman, H. (2014). Religious and ethnic discrimination: Differential implications for social support engagement, civic involvement, and political consciousness. Journal of Social and Political Psychology, 2, 347-376. 